\title{
Anatomical Parameters of the Rectus Capitis Posterior Minor Muscle Based on a New Magnetic Resonance Scan Method
}

\author{
Parámetros Anatómicos del Músculo Recto Posterior Menor de la Cabeza \\ Basado en un Nuevo Método de Escaner con Resonancia Magnética
}

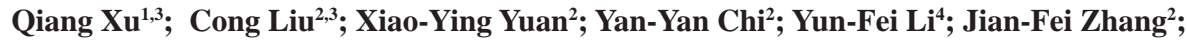 \\ Hong-Jin Sui ${ }^{2}$; Seung-Ho Han ${ }^{5}$; Sheng-Bo Yü \& Xiang-Tao Lin ${ }^{1^{*}}$
}

XU, Q.; LIU, C.; YUAN, X. Y.; CHI, Y. Y.; LI, Y. F.; ZHANG, J. F.; SUI, H. J.; HAN, S. H.; YU, S. B. \& LIN, X. T. Anatomical parameters of the rectus capitis posterior minor based on a new MRI scan method. Int. J. Morphol., 35(3):1010-1015, 2017.

SUMMARY: The past findings confirm that the Rectus Capitis Posterior minor (RCPmi) is connected to the cervical spinal dura mater via the Myodural Bridge (MDB) through the posterior antlanto-occipital interspace. It is hypothesized to perform some functions. Furthermore, some clinical studies found that the pathology of RCPmi might be related to chronic headaches. But few studies were related to the morphological parameters of the RCPmi. It would be conducive to performing clinical researches on the RCPmi and MDB. To explore the optimal section for measuring the RCPmi by MRI and provide imaging anatomy parameters of the RCPmi for clinical research. The RCPmi was measured in the dissection of 10 formalin-fixed cadaver specimens. The morphological parameters of the RCPmi were obtained. Based on these parameters, T2-weighted images of the RCPmi were collected from 109 healthy adults by using the MRIs with different oblique sagittal scanning angles. The parameters of length and area of the RCPmi on the scanning sections were measured using MRI workstation and Mimics software. The length of RCPmi reached a maximum at 30 degrees scanning leaned from the posterior median line through the dens of the axis in oblique sagittal section. At this scanning section, the length of RCPmi was $21.2 \pm 2.6 \mathrm{~mm}$ in males and $19.3 \pm 2.4 \mathrm{~mm}$ in females and the area of RCPmi was $91.9 \pm 27.2 \mathrm{~mm}^{2}$ in males and $73.3 \pm 22 \mathrm{~mm}{ }^{2}$ in females. These parameters of RCPmi were present with significant gender differences $(\mathrm{P}<0.05)$ but was not age related. Thirty degrees leaned from the median line was suggested to be the optimum scanning angle to display the RCPmi in oblique sagittal section. The reference values of length and area of the RCPmi were established for studies of hypertrophy or amyotrophy of the RCPmi.

KEY WORDS: Suboccipital region; Rectus capitis posterior minor muscle (RCPmi); Imaging anatomy parameters;

\section{INTRODUCTION}

The suboccipital region is a complex anatomical structure with the rectus captis posterior major (RCPma), the rectus capitis posterior minor (RCPmi), and the obliquus capitis inferior (OCI) as part of an important anatomical structure in this region for connecting with the dura mater via the myodural bridge (MDB) (Hack et al., 1995; Pontell et al., 2013; Scali et al., 2013; Su et al., 2013; Zheng et al., 2014). In the past 20 years, it was proposed that through the MDBs the RCPmi might perform some physiological functions, like protecting the spinal cord from dural enfolding (Chang et al., 1992; Hack et al.; McPartland et al., 1997; Fernández-de-Las-Peñas et al., 2008; Pontell et al.), placing tension to the dura under (Chang et al.; McPartland et al.; Rutten et al., 1997; Fernández-de-Las-Peñas et al., 2008;), maintaining the integrity of the subarachnoid space (McPartland et al.; Fernández-de-Las-Peñas et al., 2008), and working as a pump via the MDBs to provide power for CSF circulation ( $\mathrm{Su}$ et al.; Zheng et al.; Yuan et al., 2016). Furthermore, Some clinical studies found that the pathology of the suboccipital muscles, for instance atrophy or swelling of the RCPmi, might be closely related to chronic cervical headaches (McPartland et al.; Alix \& Bates, 1999; Fernándezde-Las-Peñas et al., 2007; Fernández-de-Las-Peñas et al., 2008). Although the RCPmi has been studied with emphasis

\footnotetext{
${ }^{1}$ Shandong University School of Medicine, Jinan, Shandong, 250014, China.

${ }^{2}$ Department of Anatomy, Dalian Medical University, Dalian, Liaoning 116044, China.

${ }^{3}$ Department of Radiology, Huanghai Hospital, Dalian, Liaoning 116021, China.

${ }^{4}$ College of Zhongshan, Dalian Medical University, Dalian, Liaoning 116085, China.

${ }^{5}$ Department of Anatomy, College of Medicine, Chung-Ang University, Seoul 156-756, Korea.

The present work is supported by Natural Science Foundation of China (NSFC31571234), Natural Science Foundation of Liaoning province (2014023017), and Department of Education Foundation of Liaoning province (L2015156)..
} 
on their physiological and pathological significance, there is a paucity of data in the imaging anatomical parameters of this muscles. Therefore, the purpose of this study was to provide imaging anatomical parameters of the RCPmi by anatomical dissections and MRI imaging.

\section{MATERIAL AND METHOD}

Approval for this study was obtained from the Ethics Committee for Research of Basic Medical College of Dalian Medical University.

Measurement of the RCPmi in dissected neck specimens. Ten formalin -fixed adult male cadaveric specimens were dissected at the suboccipital region. The superficial structures of the upper back were removed to expose RCPmi from their point of origin to insertion; then morphological parameters of the RCPmi were measured. The measurements include the length of medial and lateral margins of RCPmi and the angle between them, and the width of the origin and insertion of RCPmi (Fig. 1). Based on the angle value, the length of the RCPmi along the angle bisector was measured (Fig. 1).

MR imaging measurement of the RCPmi in volunteers. One hundred and nine healthy adults (47 males and 62 females, age range from 19 to 70 years with an average of $39.2 \pm 14.1$ years) were included in the study. No pathological changes were found in the necks of volunteers.
Informed consent was obtained from all volunteers.

A 0.35T MRI scanner (BTI-035, Shengzhen Basda Medical Apparatus Co., Ltd.) was used with a neck coil phased array. The scanning sequence T2WI/FSE (TR/TE $3,200 \mathrm{~ms} / 115 \mathrm{~ms}$ ) was employed with a thickness of $5 \mathrm{~mm}$, interval of $1 \mathrm{~mm}, 256$ X 279 matrix, 272 X $272 \mathrm{~mm}$ view field, and two activations.

The left RCPmi was imaged by T2-weighted scanning with seven kinds of scanning angles separately, including 0 , $25,30,35,40,45$, and 50 degrees. The 0 degree scanning section was five millimeters left to the median sagittal plane and the others pivoted on the dens of the axis (C2) and turned to left with $25,30,35,40,45$, and 50 degrees respectively (Fig. 2). The oblique sagittal plane T2-weighted images of RCPmi according to scanning degrees were collected. After that, the length of RCPmi was measured by MR workstation. The section with the longest RCPmi was selected as the optimal one to show. And then in this section, the area of RCPmi was measured by Mimics software 16.0 (Belgium), and the whole length of the RCPmi from origin to insertion was measured as well (Fig. 3).

Analysis of data. The range, $95 \%$ confidence interval, mean, and standard deviation of the morphological parameters of the RCPmi were calculated. Comparisons between the adjacent angles, sexs or age groups were tested using OneWay ANOVA analysis and a paired sample T-test. A p value of less than 0.05 indicated a statistically significant difference.

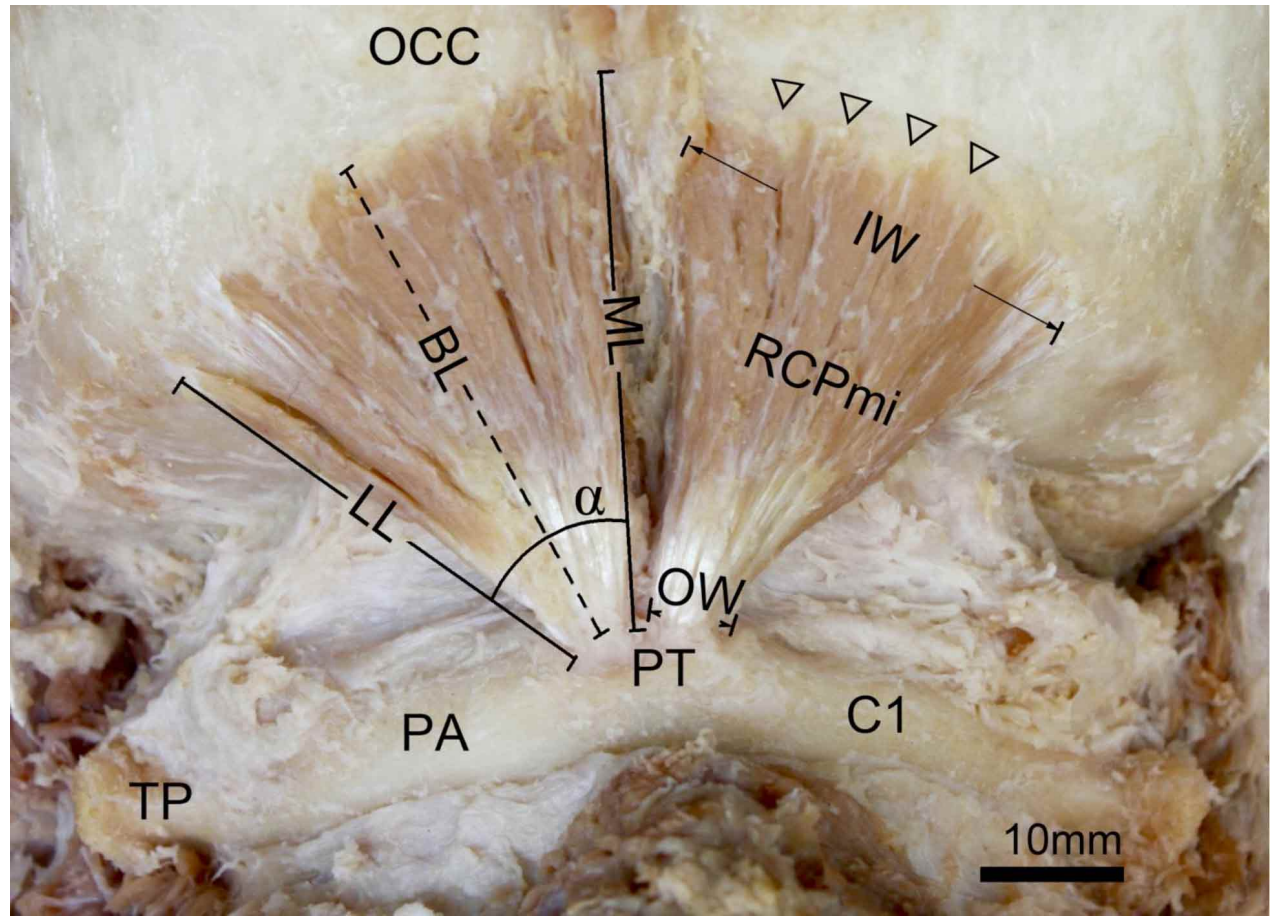

Fig. 1. Measurements of the RCPmi in a case of the specimens (dorsal and inferior view). The a was an angle between the medial and lateral margins of the RCPmi. The LL showed the length of the lateral margin, and the ML showed the length of the medial margin of the RCPmi. The BL showed the length of the RCPmi along its angle bisector. The OW showed the width of the origin of RCPmi, and the IW showed the width of the insertion of the RCPmi. OCC, the occipital bone. RCPmi, the rectus capitis posterior minor. $\nabla \mathrm{s}$, the inferior nuchal line, the insertion of the RCPmi. $\mathrm{PT}$, the origin of the RCPmi, the posterior tubercle of the atlas arch. PA, the posterior arch of the atlas. TP, the transverse process of the atlas. $\mathrm{C} 1$, the atlas. 


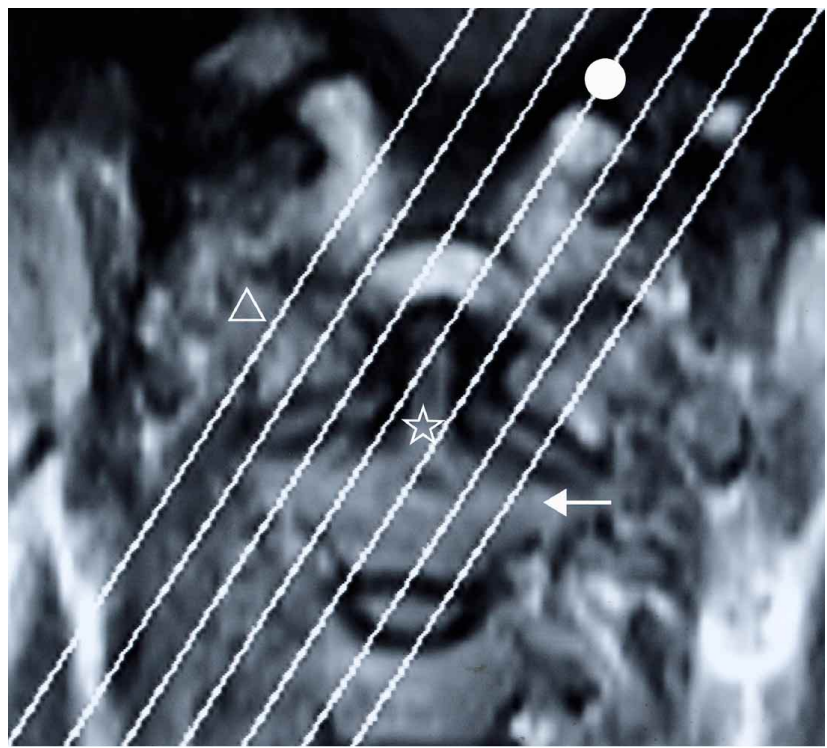

Fig. 2. Definition of MR scanning reference lines, a case of 30 degree scanning. $\bullet$, showing the 30 degree scanning line through the dens of axis. $*$, the dens of axis. $\Delta$, the atlas. $\Leftarrow$, the axis. In each scanning, the T2 weighted image, which passed through the dens of the axis, was collected for measurements.

\section{RESULTS}

Anatomical parameters of RCPmi measured in dissected specimen. In the suboccipital region, the RCPmi

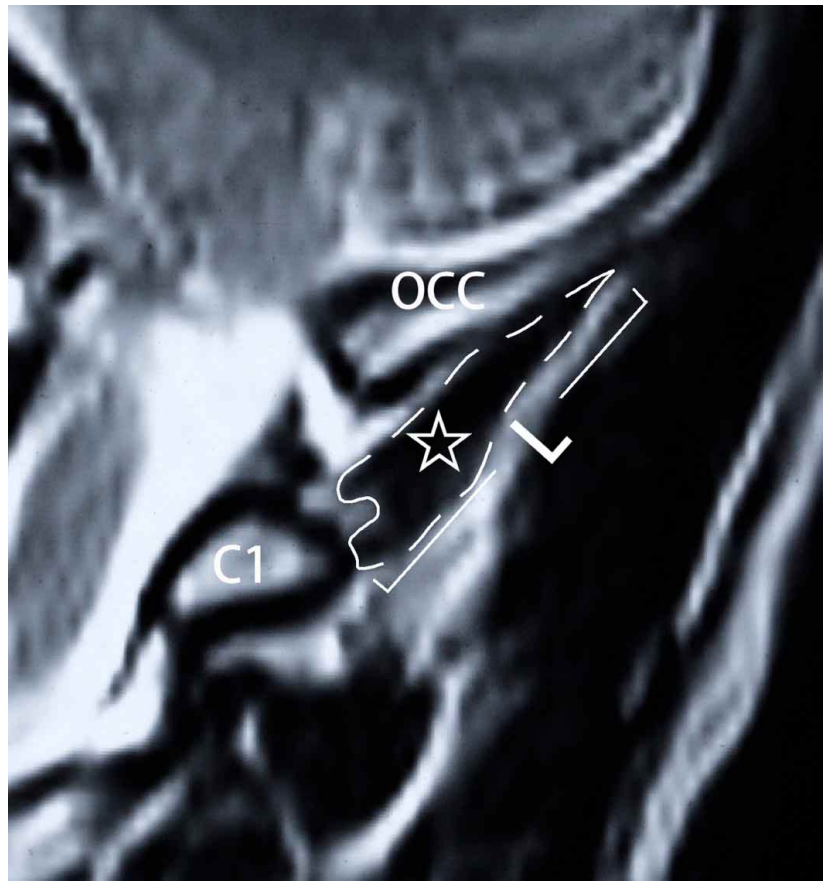

Fig. 3. A case of T2WI image of the RCPmi with thirty-degree bias from the oblique sagittal plane. The RCPmi (?) is presented in the region of low signal. The $\mathrm{L}$ showed the length of the RCPmi and the range of its area measurement was outlined by the dotted line. OCC, occipital bone. $\mathrm{C} 1$, the atlas.

was exposed from the posterior tubercle of the atlas to the inferior nuchal line of the occipital bone. It was found to be

Table I. Anatomical parameters of the RCPmi in male adult cadaver specimens ( $\mathrm{n}=17$ sides).

\begin{tabular}{lclllll}
\hline Value & Angle _ (degree) & ML $(\mathrm{mm})$ & LL $(\mathrm{mm})$ & BL $(\mathrm{mm})$ & OW $(\mathrm{mm})$ & IW (mm) \\
\hline rangs & $55.0-72.0$ & $20.5-39.2$ & $18.6-42.2$ & $15.8-36.2$ & $5.5-11.0$ & $17.7-34.9$ \\
$95 \%$ confidence intervals & $58.5-62.9$ & $24.4-29.6$ & $21-28$ & $25.2-30.3$ & $7.2-8.7$ & $24.9-29.6$ \\
Mean \pm SD & $60.7 \pm 4.4$ & $27.0 \pm 5.0$ & $24.5 \pm 6.8$ & $27.8 \pm 5.0$ & $7.9 \pm 1.4$ & $27.2 \pm 4.6$ \\
\hline
\end{tabular}

Note: the LL showed the length of the lateral margin, and the ML showed the length of the medial margin of the RCPmi. The BL showed the length of the RCPmi along its angle bisector. The OW showed the width of the origin of RCPmi, and the IW showed the width of the insertion of the RCPmi.

Table II. Length of the RCPmi with different oblique sagittal sections (mm).

\begin{tabular}{cccccc}
\hline Rang & $\begin{array}{c}95 \% \text { confidenc } \\
\text { e intervals }\end{array}$ & Mean \pm SD & Rang & $\begin{array}{c}95 \% \text { confidence } \\
\text { intervals }\end{array}$ & Mean \pm SD \\
\hline $15.2-27.1$. & $18.7-20.3$ & $19.5 \pm 2.7$ & $12-22.5$ & $17-18.2$ & $17.6 \pm 2.3$ \\
$13.6-25.3$ & $18.9-20.4$ & $19.7 \pm 2.6$ & $12.4-23.4$ & $17.3-18.4$ & $17.9 \pm 2.2$ \\
$15.7-26.7$ & $20.5-22$ & $21.2 \pm 2.6$ & $12.4-24$ & $18.7-19.9$ & $19.3 \pm 2.4$ \\
$15-24.3$ & $18.8-20.2$ & $19.4 \pm 2.4$ & $11.6-23.3$ & $16.9-18.1$ & $17.5 \pm 2.3$ \\
$14.1-23.3$ & $17.7-19$ & $18.4 \pm 2.2$ & $10.7-22.5$ & $15.9-17.1$ & $16.5 \pm 2.3$ \\
$13.9-22.4$ & $17-18.2$ & $17.6 \pm 2.1$ & $10.2-21.4$ & $15.1-16.3$ & $15.7 \pm 2.2$ \\
$12.4-23.3$ & $15.9-17.2$ & $16.6 \pm 2.2$ & $7.3-20.3$ & $14.2-15.4$ & $14.8 \pm 2.3$ \\
\hline
\end{tabular}

Note: *there were statistical significances in the length of the RCPmi between adjacent scanning angles $(\mathrm{P}<0.05)$ except that between the 0 and 25-degree groups $(\mathrm{P}>0.05)$. 
a fan shaped muscle with $60.7 \pm 4.4$ degrees. The medial margin of the RCPmi lateral to the posterior median line was $27.0 \pm 5.0 \mathrm{~mm}$ long and the lateral margin was $24.8 \pm$ $6.8 \mathrm{~mm}$ long. The length of the RCPmi along the angle bisector was $27.8 \pm 5.0 \mathrm{~mm}$. And the widths of the origin and insertion of the RCPmi were 7.9 \pm 1.4 and $27.2 \pm 4.6$ respectively. The anatomical parameters of the RCPmi are summarized in Table I. In addition, RCPmi was absent on either sides of one of the subjects. Consequently, the RCPmi of only 17 specimens were accounted for.

Imaging anatomical parameters of the RCPmi. Based on the multi-angles scanning, Length of the RCPmi was measured in variation scanning sections and shown in Table II. It was found that the length of RCPmi varied according to variation of the scanning angles. The length of RCPmi was significantly different between adjacent scanning angles except between the 0 and 25 degrees. At 30 degrees scanning,

Table III. The whole length from origin to insertion of the RCPmi with 30-degree oblique sagittal plane.

\begin{tabular}{lcc}
\hline \multicolumn{1}{c}{ Value } & Male $(\mathrm{n}=47)$ & Female $(\mathrm{n}=62)$ \\
\hline Ranges & $18.3-33.3$ & $16.5-29.8$ \\
$95 \%$ confidence & $25.2-27.1$ & $22.5-23.8$ \\
Mean \pm SD & $26.2 \pm 3.3$ & $23.1 \pm 2.6$ \\
$F$ value & \multicolumn{2}{c}{29.629} \\
$P$ value & \multicolumn{2}{c}{0.000} \\
\hline
\end{tabular}

Note: the unit of the area was $\mathrm{mm}^{2}$. the length of RCPmi reached a maximum. Consequently, this oblique sagittal scanning angle could be regarded as the optimum to reveal the RCPmi. At this angle, its length was $21.2 \pm 2.6 \mathrm{~mm}$ in males and $19.3 \pm 2.4 \mathrm{~mm}$ in females with a significant sex difference $(p<0.05)$. In addition, the length of the RCPmi from its origin to insertion was $26.2 \pm 3.3 \mathrm{~mm}$ in males and $23.1 \pm 2.6 \mathrm{~mm}$ in females with a significant sex difference $(\mathrm{P}<0.05)$ (Table III).

Furthermore, the sectional area of the RCPmi at 30 degrees scanning was measured with $91.9 \pm 27.2 \mathrm{~mm} 2$ in males and $73.3 \pm 22.0 \mathrm{~mm} 2$ in females. The sex difference was statistically significant $(\mathrm{P}<0.05)$ (Table IV). In order to explore age changes in the RCPmi, the male and female groups where further divided into two age groups, greater than 45 years old and less than or equal to 45 years old respectively. There were no age changes in the length and area of the RCPmi in males and in females (Tables V, VI).

Table IV. The sectional area of the RCPmi with 30-degree oblique sagittal plane.

\begin{tabular}{lll}
\hline Value & Male $(\mathrm{n}=47)$ & Female $(\mathrm{n}=62)$ \\
\hline Rangs & $41.7-156.2$ & $30.8-128.3$ \\
95\% confidence & $84.0-99.9$ & $67.8-78.9$ \\
intervals & & \\
Mean \pm SD & $91.9 \pm 27.2$ & $73.3 \pm 22.0$ \\
F value & & 15.581 \\
P value & & 0.000 \\
\hline
\end{tabular}

Note: the unit of the area was $\mathrm{mm}^{2}$.

Table V. Aging change of the length from origin to insertion of the RCPmi with 30-degree oblique sagittal plane.

\begin{tabular}{lcccc}
\hline Value & \multicolumn{2}{c}{ Male $(\mathrm{n}=47)$} & \multicolumn{2}{c}{ Female $(\mathrm{n}=62)$} \\
\cline { 2 - 5 } & $\leq 45$ years old & $>45$ years old & $\leq 45$ years old & $>45$ years old \\
& $(\mathrm{n}=32)$ & $(\mathrm{n}=15)$ & $(\mathrm{n}=40)$ & $(\mathrm{n}=22)$ \\
Ranges & $18.3-33.3$ & $21.9-29.4$ & $16.6-29.8$ & $16.5-26.8$ \\
$95 \%$ confidence intervals & $24.9-27.5$ & $24.8-27.4$ & $22.4-24.1$ & $21.7-23.8$ \\
Mean \pm SD & $26.2 \pm 3.7$ & $26.1 \pm 2.3$ & $23.3 \pm 2.7$ & $22.8 \pm 2.4$ \\
F value & \multicolumn{2}{c}{0.002} & \multicolumn{2}{c}{0.545} \\
P value & \multicolumn{2}{c}{0.961} & \multicolumn{2}{c}{0.463} \\
\hline
\end{tabular}

Note: the unit of the area was $\mathrm{mm}^{2}$.

Table VI. Aging change of the sectional area of the RCPmi with 30-degree bias from the sagittal plane.

\begin{tabular}{|c|c|c|c|c|}
\hline \multirow[t]{2}{*}{ Value } & \multicolumn{2}{|c|}{ Male $(n=47)$} & \multicolumn{2}{|c|}{ Female $(n=62)$} \\
\hline & $\begin{array}{c}\leq 45 \text { years old } \\
\quad(n=32)\end{array}$ & $\begin{array}{c}>45 \text { years old } \\
(\mathrm{n}=15)\end{array}$ & $\begin{array}{c}\leq 45 \text { years old } \\
(n=40)\end{array}$ & $\begin{array}{c}>45 \text { years old } \\
(\mathrm{n}=22)\end{array}$ \\
\hline Ranges & $45.8 \pm 158.2$ & $41.7 \pm 132.1$ & $34.1 \pm 109.6$ & $30.8 \pm 128.3$ \\
\hline $95 \%$ confidence intervals & $86.3 \pm 105.4$ & $68.2 \pm 98.7$ & $66.9 \pm 80.6$ & $62.2 \pm 83.0$ \\
\hline Mean \pm SD & $95.8 \pm 26.5$ & $83.5 \pm 27.5$ & $73.8 \pm 21.5$ & $72.6 \pm 23.4$ \\
\hline $\mathrm{F}$ value & \multicolumn{2}{|c|}{2.172} & \multicolumn{2}{|c|}{0.038} \\
\hline P value & \multicolumn{2}{|c|}{0.147} & \multicolumn{2}{|c|}{0.847} \\
\hline
\end{tabular}

Note: the unit of the area was $\mathrm{mm}^{2}$. 


\section{DISCUSSION}

In the past 20 years, the findings confirm that the RCPmi is connected to the cervical spinal dura mater via the MDB through the posterior antlanto-occipital interspace (Hack et al.; Scali et al., 2013; Pontell et al.; Su et al.; Zheng et al.). It is hypothesized to perform some physiological functions, such as protecting the spinal cord from dural enfolding (Hack et al.; Pontell et al.; Chang et al.; Fernández-de-Las-Peñas et al., 2008; McPartland et al.), placing tension to the dura under (Rutten et al., 1997; Chang et al.; Fernández-de-Las-Peñas et al., 2008; McPartland et $a l$.$) , maintaining the integrity of the subarachnoid space$ (Fernández-de-Las-Peñas et al., 2008; McPartland et al.), and working as a pump via the MDBs to provide power for CSF circulation (Su et al.; Zheng et al.; Yuan et al.). Furthermore, Some clinical studies found that the pathology of RCPmi for instance atrophy or swelling, might be closely related to chronic cervical headaches (McPartland et al.; Alix \& Bates; Fernández-de-Las-Peñas et al., 2007; Fernándezde-Las-Peñas et al., 2008).

In this study it was found that the RCPmi covered the posterior atlanto-occipital interspace and was fan-shaped with a (60.7 \pm 4.4$)$-degree central angle. It presented with significant length variations according to the variation of the scanning angles by the MRI. As a result, it was suggested that the 30-degree scanning angle in T2-weighted images might be optimum for showing the RCPmi because the length of the RCPmi was the longest in this oblique sagittal section. In this study, a reference value of imaging anatomical parameters of the RCPmi was set up on the basis of the scanning section of 30-degree angle: the length of the RCPmi was $21.2 \pm 2.6 \mathrm{~mm}$ in male and $19.3 \pm 2.4 \mathrm{~mm}$ in female, and the area of the RCPmi was $(91.9 \pm 27.2) \mathrm{mm} 2$ in male and $(73.3 \pm 22.0) \mathrm{mm} 2$ in female. The length and area parameters of the RCPmi were found with significant sex differences and without any age difference.

Furthermore, the whole length of RCPmi was $26.2 \pm 3.3 \mathrm{~mm}$, measured from its origin and insertion in 30degree MRI images. It was similar to the length with $27.8 \pm$ $5.0 \mathrm{~mm}$ measured along the angle bisector of the RCPmi in dissected specimen. This showed that the method of MRI measurement of the RCPmi was appropriate in this study.

Many anatomical studies have focused on the connections of RCPmi in the past (Hack et al.; Rutten et al.; Yuan et al.; Alix \& Bates; Elliott et al., 2005; Zumpano et al., 2006; Hallgren, 2014; Hallgren et al., 2014; Scali et al., 2015), while few studies were related to the morphological parameters of the RCPmi. In this study, a quantitative MRI measurement of the RCPmi was developed and a reference value of imaging anatomical parameters of the RCPmi was set up. The results of this study lay basis for basic and clinical research on the RCPmi and its MDB.

\section{ACKNOWLEDGMENTS}

We give our sincere thanks to the doctors in Dalian Huanghai Hospital for assisting us with the image acquisition, and to all the volunteers for their cooperation in completing this study. We also thank Master Shuang Liu (a graduate from Shenyang Normal University) and Doctor Okoye Chukwuemeka Samuel (a postgraduate at Dalian Medical University) for their assistance in literature review and language polishing.

XU, Q.; LIU, C.; YUAN, X. Y.; CHI, Y. Y.; LI, Y. F.; ZHANG, J. F.; SUI, H. J.; HAN, S. H.; YU, S. B. \& LIN, X. T. Parámetros Anatómicos del músculo recto posterior menor de la cabeza basado en un nuevo método de escaneo con resonancia magnética. Int. J. Morphol., 35(3):1010-1015, 2017.

RESUMEN: Hallazgos previos confirman que el músculo rector posterior menor de la cabeza (mRPMC) está conectado a la duramadre cervical por medio del puente miodural (PMD) a través del espacio intermedio antlanto-occipital posterior. Se plantea la hipótesis de su capacidad para realizar algunas funciones. Además, estudios clínicos encontraron que la patología del mRPMC podría estar relacionada con dolores de cabeza crónicos. Sin embargo, pocos estudios se relacionaron con los parámetros morfológicos del mRPMC. Se buscará realizar investigaciones clínicas sobre el mRPMC y el PMD, además de explorar la sección óptima que permita medir el mRPMC por resonancia magnética (RM) y que permita obtener la imagen adecuada para la identificación de los parámetros anatómicos del mRPMC en la investigación clínica. Se midió el mRPMC durante la disección de 10 especímenes, correspondientes a cadáveres fijados con formalina. Se obtuvieron los parámetros morfológicos del mRPMC. Basándose en estos parámetros, se estudiaron imágenes ponderadas en T2 del mRPMC de 109 adultos sanos, utilizando las resonancias magnéticas con diferentes ángulos de exploración sagital oblicua. Los parámetros de longitud y área del mRPMC en las secciones de exploración se midieron utilizando la estación de trabajo del equipo de RM y el software Mimics. La longitud del mRPMC alcanzó un máximo de 30 grados de exploración, inclinado desde la línea mediana posterior, a través del eje en la sección sagital oblicua. En esta sección la longitud del mRPMC fue 21,2 $\pm 2,6 \mathrm{~mm}$ en los hombres y 19,3 $\pm 2,4 \mathrm{~mm}$ en las mujeres, y el área del mRPMC fue $91,9 \pm 27,2 \mathrm{~mm}^{2}$ en los hombres y $73,3 \pm 22 \mathrm{~mm}^{2}$ en las mujeres. Se observaron diferencias significativas de sexo en estos parámetros del mRPMC $(\mathrm{P}<0,05)$ sin embargo estos no estaban relacionados con la edad. Se sugirieron 30 grados inclinados a partir de la línea mediana como el ángulo óptimo de exploración para mostrar el 
mRPMC en la sección sagital oblicua. Los valores de referencia de longitud y área del mRPMC se establecieron para estudios de hipertrofia o amiotrofia del mRPMC.

PALABRAS CLAVE: Región suboccipital; Músculo recto posterior menor de la cabeza; Parámetros de anatomía de imagen; Resonancia magnética.

\section{REFERENCES}

Alix, M. E. \& Bates, D. K. A proposed etiology of cervicogenic headache: the neurophysiologic basis and anatomic relationship between the dura mater and the rectus posterior capitis minor muscle. J. Manipulative Phsyiol. Ther, 22(8):534-9, 1999.

Chang, H.; Gilbertson, L. G.; Goel, V. K.; Winterbottom, J. M.; Clark, C. R. \& Patwardhan, A. Dynamic response of the occipito-atlanto-axial (C0-C1-C2) complex in right axial rotation. J. Orthop. Res., 10(3):44653, 1992.

Elliott, J. M.; Galloway, G. J.; Jull, G. A.; Noteboom, J. T.; Centeno, C. J. \& Gibbon, W. W. Magnetic resonance imaging analysis of the upper cervical spine extensor musculature in an asymptomatic cohort: an index of fat within muscle. Clin. Radiol., 60(3):355-63, 2005.

Fernández-de-Las-Peñas, C.; Bueno, A.; Ferrando, J.; Elliott, J. M.; Cuadrado, M. L. \& Pareja, J. A. Magnetic resonance imaging study of the morphometry of cervical extensor muscles in chronic tension-type headache. Cephalalgia, 27(4):355-62, 2007.

Fernández-de-Las-Peñas, C.; Cuadrado, M. L.; Arendt-Nielsen, L.; Ge, H. Y. \& Pareja, J. A. Association of cross-sectional area of the rectus capitis posterior minor muscle with active trigger points in chronic tensiontype headache: a pilot study. Am. J. Phys. Med. Rehabil., 87(3):197203, 2008.

Hack, G. D.; Koritzer, R. T.; Robinson, W. L.; Hallgren, R. C. \& Greenman, P. E. Anatomic relation between the rectus capitis posterior minor muscle and the dura mater. Spine, 20(23):2484-6, 1995.

Hallgren, R. C. Modeling length-tension properties of RCPm muscles during voluntary retraction of the head. Man. Ther, 19(4):319-23, 2014.

Hallgren, R. C.; Pierce, S. J.; Prokop, L. L.; Rowan, J. J. \& Lee, A. S. Electromyographic activity of rectus capitis posterior minor muscles associated with voluntary retraction of the head. Spine J., 14(1):10412, 2014.

McPartland, J. M.; Brodeur, R. R. \& Hallgren, R. C. Chronic neck pain, standing balance, and suboccipital muscle atrophy--a pilot study. $J$. Manipulative Physiol. Ther, 20(1):24-9, 1997.

Pontell, M. E.; Scali, F.; Marshall, E. \& Enix, D. The obliquus capitis inferior myodural bridge. Clin. Anat., 26(4):450-4, 2013.

Rutten, H. P.; Szpak, K.; van Mameren, H.; Ten Holter, J. \& de Jong, J. C. Anatomic relation between the rectus capitis posterior minor muscle and the dura mater. Spine (Phila Pa 1976), 22(8):924-6, 1997.

Scali, F.; Pontell, M. E.; Nash, L. G. \& Enix, D. E. Investigation of meningomyovertebral structures within the upper cervical epidural space: a sheet plastination study with clinical implications. Spine J., 15(11):2417-24, 2015.

Scali, F.; Pontell, M. E.; Welk, A. B.; Malmstrom, T. K.; Marshall, E. \& Kettner, N. W. Magnetic resonance imaging investigation of the atlantoaxial interspace. Clin. Anat., 26(4):444-9, 2013.

Su, H. J.; Yu, S. B.; Yuan, X. Y.; Gao, H. B.; Xu, G.; Li, Y. F. \& Chi, Y. Y. Anatomical study on the connections between the suboccipital structures and the spinal dura mater. Chin. J. Clin. Anat., (4):489-90, 2013.

Yuan, X. Y.; Yu, S. B.; Li, Y. F.; Chi, Y. Y.; Zheng, N.; Gao, H. B.; Luan, B. Y.; Zhang, Z. X. \& Sui, H. J. Patterns of attachment of the myodural bridge by the rectus capitis posterior minor muscle. Anat. Sci. Int., 91(2):175-9, 2016.
Zheng, N.; Yuan, X. Y.; Li, Y. F.; Chi, Y. Y.; Gao, H. B.; Zhao, X.; Yu, S. B.; Sui, H. J. \& Sharkey, J. Definition of the to be named ligament and vertebrodural ligament and their possible effects on the circulation of CSF. PLoS One, 9(8):e103451, 2014.

Zumpano, M. P.; Hartwell, S. \& Jagos, C. S. Soft tissue connection between rectus capitus posterior minor and the posterior atlanto-occipital membrane: a cadaveric study. Clin. Anat., 19(6):522-7, 2006.

\author{
Corresponding author: \\ Prof. Dr. Xiang-Tao Lin \\ Shandong University School of Medicine \\ Jinan, 250014 \\ CHINA
}

E-mail address: linxt@sdu.edu.cn

Received: 10-04-2017

Accepted: 05-06-2017 